\title{
IMPLIKASI PEMBERDAYAAN LEMBAGA ADAT SEBAGAI ALTERNATIF DALAM PENYELESAIAN SENGKETA PERTANAHAN DI ACEH
}

\author{
Wahyu Ramadhani ${ }^{1}$, Ida Safitri ${ }^{2}$ \\ ${ }^{I}$ Dosen Prodi Hukum Universitas Sains Cut Nyak Dhien Langsa Jln. Ahmad Yani No. 218 \\ Kota Langsa - Aceh, ${ }^{2}$ Dosen Pendidikan Biologi \\ Universitas Sains Cut Nyak Dhien Langsa Jln. Ahmad Yani No. 218 Kota Langsa - Aceh \\ ${ }^{1}$ wahyu_ramadhani95@yahoo.com, ${ }^{2}$ ida.safitri27@gmail.com
}

\begin{abstract}
Article 18B Paragraph (2) of the 1945 Constitution states that the state recognizes and respects the units of customary law communities and their traditional rights as long as they are still alive and in accordance with the principles of the Unitary State of the Republic of Indonesia. The problem of this research is first, how is the resolution of land disputes through traditional institutions in Aceh and what are the implications for the empowerment of traditional institutions as an alternative in the resolution of land disputes in Aceh. This research uses the Empirical J uridical approach. J uridical empirical research is a direct approach to spaciousness by obtaining data. This shows institutionally the dispute resolution mechanism through adat institutions still faces many obstacles. National legal politics that prioritize legal unification is still felt juridically so far, related to the authority of institutions to settle disputes that adat institutions have their structure, duties and functions as well as their competencies. The implication in the resolution of land disputes in Aceh is the mechanism of deliberation, that is, the settlement of promoting muyawarah is a positive one of the mechanism of dispute resolution through adat institutions.
\end{abstract}

Keywords: Customary Institutions, Dispute Resolution, Land

\begin{abstract}
Abstrak, Pasal 18B Ayat (2) UUD 1945 menyatakan negara mengakui serta menghormati kesatuan-kesatuan masyarakat hukum adat beserta hak-hak tradisionalnya sepanjang masih hidup dan sesuai dengan prinsip Negara Kesatuan Republik Indonesia. Permasalahan dari penelitian ini pertama, bagaimana penyelesaian sengketa pertanahan melalui lembaga adat di Aceh dan Apa implikasi dalam pemberdayaan lembaga Adat sebagai alternatif dalam penyelesaian Perkara sengketa pertanahan di Aceh. Penelitian ini menggunakan metode pendekatan Yuridis Empiris. Yuridis empiris adalah penelitian dengan pendekatan langsung kelapangan dengan memperoleh data. Hal ini menunjukkan secara kelembagaan mekanisme penyelesaian sengketa melalui lembaga adat masih menghadapi banyak kendala. Politik hukum nasional yang mengedepankan unifikasi hukum masih dirasakan dampaknya secara yuridis sampai saat ini, terkait dengan kewenangan lembaga menyelesaikan sengketa bahwa lembaga adat memiliki struktur, tugas dan fungsi serta kompetensinya. Implikasi dalam penyelesaian sengketa pertanahan di Aceh adalah mekanisme musyawarah yaitu penyelesaian mengedepankan muyawarah merupakan salah satu yang positif dari mekanisme penyelesaian sengketa melalui lembaga adat.
\end{abstract}

KataKunci : Lembaga Adat, Penyelesain Sengketa, Pertanahan 


\section{Pendahuluan}

Indonesia merupakan negara kepulauan yang terdiri dari banyak pulau dan memiliki berbagai macam suku bangsa, bahasa dan adat istiadat. Keanekaragaman budaya yang terdapat di Indonesia merupakan suatu bukti bahwa Indonesia merupakan negara yang kaya akan budaya. Tidak bisa kita pungkiri, bahwa kebudayaan daerah merupakan faktor utama berdirinya kebudayaan yang lebih global, yang biasa kita sebut dengan kebudayaan nasional. Maka atas dasar itulah segala bentuk kebudayaan daerah akan sangat berpengaruh terhadap budaya nasional, begitu pula sebaliknya kebudayaan nasional yang bersumber dari kebudayaan daerah, akan sangat berpengaruh pula terhadap kebudayaan daerah / kebudayaan lokal.

Pasal 18B Ayat (2) UUD 1945 Amandemen ke- 4 menyatakan negara mengakui serta menghormati kesatuan-kesatuan masyarakat hukum adat beserta hak-hak tradisionalnya sepanjang masih hidup dan sesuai dengan prinsip Negara Kesatuan Republik Indonesia. Beranjak dari masalah hukum agrarian maka dasar hukum di Indonesia telah mengaturnya kedalam Undang-undang Pokok Agraria Nomor 5 Tahun 1960 tentang Peraturan Dasar Pokok-Pokok Agraria (UUPA).

Diakuinya hak ulayat didalam UUPA dalam Pasal 3 UUPA yang menyatakan bahwa Hak ulayat adalah hak dari persekutuan hukum adat, untuk menggunakan dengan bebas tanah-tanah yang masih merupakan hutan belukar di dalam lingkungan wilayahnya guna kepentingan persekutuan hukum itu sendiri dan anggota-anggota atau guna kepentingan orang-orang luar. ${ }^{1}$ Meskipun UUPA mengakui keberadaan hak ulayat, namun hak ulayat tersebut harus sesuai dengan kepentingan nasional dan Negara, berdasarkan persatuan bangsa dan tidak boleh bertentangan dengan undang-undang dan peraturan-peraturan lain yang lebih tinggi. ${ }^{2}$

Berangkat dari hal di atas maka Provinsi Aceh merupakan salah satu daerah keistimewaan yang diberikan oleh Negara Republik Indonesia dalam hal otonomi khusus yang dipayungi oleh Undang-undang Nomor 44 Tahun 1999 tentang Penyelenggaraan Keistimewaan Propinsi Daerah Istimewa Aceh maka dari dasar tersebutlah lahirnya Undang-Undang Pemerintah Aceh Nomor 11 Tahun 2006 tentang Pemerintah Aceh. Dalam hal adat istiadat Pemerintah Aceh mengaturnya kedalam Qanun Aceh Nomor 9 Tahun 2008 tentang pembinaan kehidupan adat dan adat istiadat ${ }^{3}$ dalam Pasal 13 menyebutkan bahwa :

(1) Sengketa/perselisihan adat dan adat istiadat meliputi:

a. perselisihan dalam rumah tangga;

b. sengketa antara keluarga yang berkaitan dengan faraidh;

c. perselisihan antar warga;

${ }^{1}$ H. Ali Achmad Chomzah, Hukum Agraria (pertanahan Indonesia) Jilid 1, (Jakarta: Prestasi pustaka, 2004), hlm. 28

${ }^{2}$ Lihat Penjelasan Undang-undang Pokok Agraria Nomor 5 Tahun 1960

3 Yusi Amdani, Proses Penyelesaian Perselisihan di lembaga peradilan adat Aceh Tingkat Gampong (Desa), Jurnal Ilmu Asyari'ah dan hukum Vol. 48 No. 1, Juni 2014, hlm. 238 
d. khalwat meusum;

e. perselisihan tentang hak milik;

f. pencurian dalam keluarga (pencurian ringan);

g. perselisihan harta sehareukat;

h. pencurian ringan;

i. pencurian ternak peliharaan;

j. pelanggaran adat tentang ternak, pertanian, dan hutan;

k. persengketaan di laut; 1 . persengketaan di pasar;

1. penganiayaan ringan;

m. pembakaran hutan (dalam skala kecil yang merugikan komunitas adat);

n. pelecehan, fitnah, hasut, dan pencemaran nama baik;

o. pencemaran lingkungan (skala ringan);

p. ancam mengancam (tergantung dari jenis ancaman); dan

q. perselisihan-perselisihan lain yang melanggar adat dan adat istiadat.

Berdasarkan qanun di atas maka dalam poin huruf e dan $\mathrm{g}$, diatur tentang penyelesaian kasus pertanahan. Dalam hal ini poin Pasal 13 huruf e perselisihan tentang hak milik dari 3 (tiga) kasus yang ada di Kecamatan bireum bayeun kabupaten aceh timur tidak satupun dapat terselesaikan karena dalam hal ini kasus pertanahan yang terjadi tentang sengketa pertanahan yang memiliki 2 (dua) kepemilikan yang berbeda tidak terselesaikan dikarenakan dalam hal ini dari kedua belah pihak tidak puas menerima putusan dari lembaga adat yang ada di kecamatan tersebut sehingga berujung ke Pengadilan Negeri.

Sementara bila kita lihat dari kasus yang lain terhadap Pasal 13 huruf g dengan perselisihan harta sehareukat melalui penyelesaian adat dari 3 (tiga) kasus yang ada di kecamatan Birem Bayeun Kabupaten Aceh Timur maka 2 (dua) kasus dapat diselesaikan secara hukum adat. Disini dapat kita ketahui bahwa perselisihan yang menyangkut atas kepemilikan yang berbeda yang tidak ada hubungan kekeluargaan sangat sulit untuk diselesaikan antara kedua belah pihak, sedangkan yang memiliki kekeluargaan seperti harta seuhareukat ${ }^{4}$ bisa diselesaikan dengan dengan baik bersama lembaga adat di sekitar.

Sementara itu bila kita kaitkan dengan Undang-Undang Pokok Agraria Nomor 5 Tahun 1960 pada Pasal 18 B negara mengakui serta menghormati kesatuan-kesatuan masyarakat hukum adat selama tidak bertentangan dengan hukum nasional serta putusan dari hukum adat di aceh didaftarkan ke Pengadilan Negeri agar memiliki kekuatan hukum yang tetap dan dapat diakui keberadaannya dalam penyelesaian melalui hukum adat yang berlaku.

Berdasarkan uraian di atas, dapat dirumuskan pokok permasalahan yang akan di dibahas secara lebih mendalam pada penulisan ini adalah bagaimana penyelesaian sengketa pertanahan melalui lembaga adat di Aceh dan Apa implikasi dalam

${ }^{4}$ Harta sehareukat adalah harta bersama yang memiliki hubungan kekeluargaan antara suami dan istri baik itu salah satu bercerai akibat meninggal dunia maupun bercerai ketika masih hidup, dalam Syahrizal, Hukum Adat dan hukum Islam di Indonesia, (Banda Aceh: Nadiya Foundation Nanggroe Aceh, 2004), hlm. 63 
pemberdayaan lembaga Adat sebagai alternatif dalam penyelesaian Perkara sengketa pertanahan di Aceh.

Penelitian ini menggunakan metode pendekatan Yuridis Empiris. Penelitian ini menggunakan teknik pengumpulan bahan hukum dan data yang terdiri dari Studi Kepustakaan (LiberaryResearch). Analisa bahan hukum dalam penelitian ini dilakukan dengan cara kualitatif dan disajikan secara deskriptif.

\section{Tinjauan Pustaka}

\section{Teori Hukum}

Humanisasi hidup dan keahlian sosial tampil sebagian kekuasaan baru yang dihadapi manusia di abad ke-20. Teori tentang hukum yang berasal dari sejumlah tokoh dengan latar belakang orientasi teoritis yang berbeda, baik dari kubu Neo-Kantian, NeoPositivisme, Neo-Marxis, kubu Fenomenologis, kubu eksistensialisme, dan juga penerus teori hukum alam abad ke-20. ${ }^{5}$

Didalam Neo Positivisme Teori Max Weber mengungkapkan bahwa hukum merupakan cermin rasionalitas dan otoritas. Titik tolak teori Weber berpangkal pada "tingkat rasionalitas dan model kekuasaan/ otorisasi". Tingkat nasionalitas masyarakat akan menentukan warna hukum dalam masyarakat itu. Tipe rasionalitas substantifirasional melahirkan wujud hukum informal irasional, tipe substantif-rasional, melahirkan wujud hukum informal-rasional, dan tipe formal-rasional melahirkan hukum dalam bentuk aturan-aturan rinci, khusus, dan terkodifikasi. ${ }^{6}$

Indonesia sendiri dalam hal pertanahan mempunyai dasar hukum yang kuat yang sudah di kodifikasikan sesuai dengan wujud pengembangan dari teori hukum NeoPositivisme. Kerangkan dasar dari Undang-undang tersebut adalah UU No. 5 Tahun 1960 Peraturan Dasar Pokok-Pokok Agraria yang kemudian dikenal dengan Undang Undang Pokok Agraria (UUPA).

Tanah memang menjadi hal penting dalam kehidupan manusia, untuk itu penting diatur keberadaannya, dan negara sebagai penguasa tanah bertanggungjawab untuk membuat peraturan tentang pertanahan tersebut. UUPA sebagai turunan dari pasal 33 ayat 3 UUD 1945 mengandung asas (prinsip) bahwa semua hak atas tanah dikuasi oleh negara, dan asas bahwa hak milik atas tanah "dapat dicabut untuk kepentingan umum". prinsip ini tertuang dalam pasal 2 dan pasal 18 UUPA. Berdasarkan pasal 2 UUPA ini negara menjadi pengganti semua pihak yang mengaku sebagai penguasa tanah yang sah. Negara dalam hal ini merupakan lembaga hukum sebagai organisasi seluruh rakyat Indonesia. Pemerintah sebagai lembaga pelaksana UU negara dalam proses ini bertindak sebagai

${ }^{5}$ I Dewa Gede Atmadja dan I Nyoman Putu Budiartha, Teori-teori Hukum, (Malang: Setera Press, 2018), hlm. 114

${ }^{6}$ Ibid 
pihak yang melaksanakan dan menerapkan ketentuan yang terdapat dalam pasal 2 UUPA tersebut. $^{7}$

Dengan demikian Menurut Syafruddin Kalo, "pemerintah menjadi pihak yang wajib dan berwenang mengatasi dan menengahi sengketa hak penguasaan atas tanah yang muncul sekaligus menjadi fasilitator bagi pihak-pihak yang terlibat dalam sengketa". Kewenangan keagrariaan ada pada pemerintah pusat namun, pada pelaksanaannya dapat dilimpahkan pada pemerintah daerah ataupun kepada persekutuan masyarakat hukum adat. $^{9}$

Status kepemilikan tanah sering menjadi muasal dari perselisihan di Indonesia, yang barangkali disebakan oleh tidak adanya ketegasan penyelenggara negara mengenai kepemilikan ini. Untuk itu berikut ini akan dikemukakan mengenai teori kepemilikan/penguasaan tanah di Indonesia.

Dalam sejarah hukum pertanahan di Indonesia sejak zaman kesultanan, zaman kolonial, sampai zaman kemerdekaan, dalam prakteknya diperlakukan 3 (tiga) teori penguasaan tanah yakni teori eropa, teori adat dan teori hukum nasional. ${ }^{10}$ Ketiga teori ini silih berganti diterapkan di Indonesia sesuai dengan zamannya masing-masing.

\section{a. Teori Eropa.}

Teori Eropa merupakan penguasaan atas tanah berdasarkan pemikiran orang eropa. Sebagaimana diketahui, bahwa pada masa lalu wilayah nusantara pernah menjadi bahagian dari wilayah kekuasaan bangsa eropa sehingga hukum pertanahan yang diterapkan oleh penguasa eropa tersebut dipengaruhi oleh pemikiran orang eropa. Sejarah eropa telah mencatat bahwa sebelum terjadinya Revolusi Prancis, di Eropa berlaku doktrin bahwa raja adalah wakil Tuhan di bumi, sehingga pada masa itu raja-raja di eropa memiliki kekuasaan yang sangat tinggi untuk mengatur negaranya, bahkan raja dianggap berkuasa atas segala hal, raja adalah penguasa negara dan raja pula berkuasa atas tanahtanah di negaranya.

Seiring dengan berkuasanya bangsa-bangsa eropa di Indonesia, maka pemikiran bahwa raja adalah penguasa mutlak atas tanah negara diberlakukan juga di Indonesia oleh penguasa bangsa eropa tersebut. dalam hal ini Kalo mencatat sebagai berikut:

Di Eropa sebelum masa Revolusi Perancis berlaku doktrin bahwa raja adalah penguasa segala hal di negaranya dengan semboyan "L'etat c'est Moi" atauNegara adalah Saya, teori ini mencerminkan kekuasaan yang besar atas tanah. Raja dianggap sebagai wakil negara dan pemilik tanah adalah negara. Teori ini juga berlaku di Inggris dan Belanda. Indonesia sebagai negara jajahan Belanda memberlakukan teori ini di Indonesia, yang berarti bahwa semua tanah di Indonesia adalah milik raja dan dengan

${ }^{7}$ Syafruddin Kalo, Perbedaan Persepsi Mengenai Penguasaan Tanah dan Akibatnya Terhadap Masyarakat Petani di Sumatera Timur pada Masa Kolonial yang Berlanjut pada Masa Kemerdekaan, Orde Baru dan Reformasi, Program Studi Hukum Pidana Fakultas Hukum Universitas Sumatera Utara, t.t. hlm. 3

${ }^{8}$ ibid

${ }^{9}$ Umar Kusumo Haryono, Eksistensi Tanah Kasultanan (Sultan Ground) Yogyakarta Setelah Berlakunya UU No. 5 / 1960, Yustisia Edisi Nomor 68 Mei - Agustus 2006, hlm. 3.

${ }^{10}$ Kalo, Op.Cit. hlm. 7. 
demikian oleh karena raja takluk kepada pemerintahan kolonial, maka semua tanah di negara jajahan dikonversi menjadi milik raja Belanda. Oleh karena itu pemerintah Kolonial menganggap semua tanah yang ada di Indonesia adalah milik penguasa kolonial. Dengan memberlakukan azas domein verklaring, dengan arti bahwa semua tanah-tanah tidak dapat dibuktikan siapa pemiliknya adalah menjadi tanah negara. Atas dasar teori ini maka pemerintah kolonial dapat menyewakan tanah-tanah kepada perusahaanonderneming dengan skala besar. ${ }^{11}$

Kebijakan pemberlakuan teori domein verklaring didasari atas alasan-alasan karena pemerintah Belanda menganggap raja-raja di Indonesia yang mempunyai kekuasaan hak domein atas tanah maka dengan sendirinya hak domein itu juga diambil over oleh Belanda karena Belanda memegang kedaulatan di Indonesia. ${ }^{12}$ Teori ini sengaja diterapkan agar pemerintah Hindia Belanda dapat memiliki tanah-tanah rakyat indonesia yang pada waktu hampir seluruhnya masih menerapkan sistem hukum adat. Karena pemilikan atas tanah berdasarkan sistem adat tidak ada satupun yang menyamai hak eigendom. ${ }^{13}$

Dasar hukum pemberlakuan domein verklaring oleh pemerintah Hindia Belanda di dasarkan kepada Agrarische Wet (staatblad 1870 nomor 118) yang terkait dengan Agrarische Wet (staatblad 1870 nomor 55). Pasal 1 Agrarische Besluit menetukan bahwa terhadap tanah-tanah yang tidak dapat dibuktikan kepemilikannya akan menjadi milik negara. ${ }^{14}$

Kebijakan pemerintah Belanda dalam memperlakukan teori domeinverklaring ini sangat merugikan rakyat karenadomein diperlakukan di atas tanah rakyat dan memungkinkan tanah-tanah hak ulayat diberikan kepada orang asing dengan hak sewa (erfacht). ${ }^{15}$ Dalam hal ini ada dua hal penting yang terkait dengan domein verklaring, yaitu:

a. Hubungan antara negara dengan tanah dipersamakan dengan hubungan antara tanah dengan perseorangan yang bersifat privaattreefhtelijk.

b. Domein verklaring tidak lebih ditujukan terhadap tanah yang tunduk pada hukum adat, mengingat dalam sistem hukum adat tidak dikenal dengan sistem pembuktian kepemilikan secara tertulis seperti yang dikenal dalam hukum barat. ${ }^{16}$

Berdasarkan teori domein verklaring, ini maka tanah-tanah adat dianggap sebagai milik negara. Akibatnya pemerintahan negara menganggap negara berwenang untuk memberikan hak erfphacht kepada investor untuk mengusahai tanah-tanah adat tersebut, demikian juga para investor merasa sah untuk menguasai dan mengusahai tanah-tanah tersebut. Di sisi lain anggota masyarakat hukum adat merasa bahwa tanah-tanah tersebut

\footnotetext{
${ }^{11}$ Ibid, hlm. 7.

${ }^{12}$ ibid

${ }^{13}$ Zuryawan Isvandiar Zoebir, Bayang-Bayang Cultuurstelsel Dan Domein Verklaring
} Dalam Praktik Politik Agraria,http://zuryawanisvandiarzoebir.wordpress.com/2008/11/07/ bayangbayang-cultuurstelsel-dan-domein-verklaring-dalam-praktik-politik-agraria/, (7 Juni 2019).

${ }^{14}$ Heru Kuswanto, Hukum Agraria, (Modul) Fakultas Hukum Universitas Narotama, Surabaya, 2011, hlm. 2

${ }^{15}$ Loc, Cithlm. 7-8

${ }^{16} \mathrm{Op}$, Cit hlm. 2 
masih merupakan milik mereka karena memang anggota-anggota masayarakat tersebut tidak pernah melepaskan haknya atas tanah-tanah adatnya itu.

Pemberlakuan teori domein ini jelas sangat merugikan rakyat pribumi (masyarakat hukum adat) karena akibat dari pemberlakuan teori tersebut maka tanah adat (ulayat) yang meskipun menurut kenyataannya masih ada dan ditaati oleh masyarakat hukum adat, tidak diakui lagi keberadaannya, karena tanah tersebut telah dikategorikan sebagai domein negara, yaitu tanah negara bebas (vrij lands domein). ${ }^{17}$

\section{c. Teori Adat}

Teori pemilikan tanah berdasarkan hukum adat adalah tanah merupakan milik komunal atau persekutuan hukum (beschikkingsrecht). Dalam hal ini setiap anggota persekutuan dapat mengerjakan tanah dengan jalan membuka tanah terlebih dahulu dan jika mereka mengerjakan tanah tersebut secara terus-menerus maka tanah tersebut dapat menjadi hak milik secara individual. ${ }^{18}$

Tentang pemilikan tanah adat ini, Ter Haar sebagaimana dikutip oleh Kalo menjelaskan sebagai berikut:Hukum adat memberikan hak terdahulu kepada orang yang dulu menaruh tanda pelarangannya atau mula-mula membuka tanah; bilama ia tidak mengerjakan pekerjaan-pekerjaan penebangan dan pembakaran menurut musimnya, maka orang lain bisa mendesaknya supaya memilih: mengerjakan terus atau menyerahkan tanahnya kepadanya. Jadi tuntutan pemilikan hak milik ini lenyap sama sekali bilamana ada lain orang sesama anggota yang menginginkannya dan mendesak dia memilih satu antara kedua pilihan itu. ${ }^{19}$

Menurut Wignjodipoero, hak persekutuan atas tanah ini disebut juga hak pertuanan atau hak ulayat, sementara Van Vollenhoven menyebutnya dengan istilah bescikkingsrecht. ${ }^{20}$ Lebih lanjut Wignjodipoero mengatakan bahwa "hak ulayat ini dalam bentuk dasarnya adalah suatu hak daripada persekutuan atas tanah yang didiami, sedangkan pelaksanaannya dilakukan atau oleh persekutuan itu sendiri atau oleh kepala persekutuan atas nama persekutuan."21 Dalam hal ini pengertian hak ulayat disebutkan sebagai berikut:Hak ulayat adalah hak suatu masyarakat hukum adat untuk menguasai tanah yang masih merupakan hutan belukar di dalam wilayahnya untuk kepentingan masayarakat hukum itu sendiri dengan para anggotanya atau untuk kepentingan orang luar masyarakat hukum itu dengan membayar uang pengakuan yang disebut atau bisa disamakan dengan recognitie. ${ }^{22}$

17 Boedi Harsono, Hukum Agraria Indonesia: Sejarah Pembentukan Undang-Undang Pokok Agraria, Isi dan Pelaksanaannya, (Jakarta: Djambatan, 1999), hlm. 46.

${ }^{18}$ Kalo, Op.Cit. hlm. 7.

${ }^{19}$ Ibid hlm. 9-10

${ }^{20}$ Wignjodipoero, Op.Cit., hlm. 198

${ }^{21}$ Ibid, hlm. 199

${ }^{22}$ Tampil Anshari Siregar, Undang Undang Pokok Agraria dalam Bagan,Kelompok Studi Hukum dan Masyarakat Fakultas Hukum USU, Medan, 2011. Hlm. 20 
Sebagai tanah ulayat persekutuan hukum adat, maka pada prinsipnya hanya anggota masyarakat hukum adat (persekutuan) itu sendiri yang boleh menggarap tanah ulayat tersebut. dalam hal ini Wignjodiopero menjelaskan sebagai berikut:Beschikkingsrechts ataupun hak ulayat ini berlaku ke luar dan ke dalam. Berlaku ke luar karena bukan warga persekutuan pada prinsipnya tidak diperbolehkan turut mengenyam/menggarap tanah yang merupakan wilayah kekuasaan persekutuan yang bersangkutan; hanya dengan seizin persekutuan serta setelah membayar pancang (uang pemasukan) dan kemudian memberikan ganti rugi, orang luar bukan warga persekutuan dapat memperoleh kesempatan untuk turut serta menggunakan tanah wilayah persekutuan.

Berlaku ke dalam karena persekutuan sebagai suatu keseluruhan yang berarti semua warga persekutuan bersama-sama sebagai suatu kesatuan, melakukan hak ulayat dimaksud dengan memetik hasil daripada tanah beserta segala tumbuh-tumbuhan dan binatang liar yang hidup atasnya. ${ }^{23}$

Adapun mengani luas wilayah tanah ulayat ini, Erman Rajagukguk sebagaiman dikutip oleh Kalo mengatakan sebagai berikut:Semua tanah, hutan, jika perlu sampai ke puncak gunung, jika penduduk mempunyai hak baik yang nyata maupun yang secara diam-diam diakui, tanah itu bukan tanah negara. Menurut hukum adat, desa mempunyai hak untuk menguasai tanah di luar perbatasan desa, penduduk desa mempunyai hak untuk menggarap atau mencari nafkah dari hutan dengan izin kepala desa. Menurut penafsiran Trenite, tanah tersebut milik negara, namun menurut pandangan Van Vollenhoven, Logeman dan Ter Haar tanah tersebut tidak di bawah kekuasaan negara. ${ }^{24}$

Lebih jelasnya tentang hak ulayat ini, Siregar menguraikan ciri-ciri hak ulayat sebagai berikut:

1. Masyarakat hukum dan para anggota-anggotanya berhak untuk dapat mempergunakan tanah hutan belukar di dalam lingkungan wilayahnya dengan bebas, yaitu bebas untuk membuka tanah, memungut hasil, berburu, mengambil ikan menggembala ternak dan lain sebagainya.

2. Bukan anggota masyarakat hukum dapat pula mempergunakan hak-hak tersebut hanya saja harus mendapat izin terlebih dahulu dari kepala masyarakat hukum dan membayar uang pengakuan atau recognite (diakui setelah memenuhi kewajibannya).

3. Masyarakat hukum beratnggungjawab atas kejahatan-kejahatan yang terjadi dalam lingkungan wilayahnya apabila pelakunya tidak dapat dikenal.

4. Masyarakat hukum tidak dapat menjual atau mengalihkan hak ulayat untuk selamalamanya kepada siapa saja.

5. Masyarakat hukum mempunyai hak campur tangan terhadap tanah-tanah yang digarap dan dimiliki oleh para anggota-anggotanya seperti dalam hal jual beli tanah dan sebagainya. ${ }^{25}$

\footnotetext{
${ }^{23}$ Ibid, hlm. 198

${ }^{24}$ Kalo, Op.Cit. hlm. 10

${ }^{25}$ Siregar, Undang-Undang, Op.Cit., hlm. 20-21
} 
Van Vollenhoven sebagaimana dikutip oleh Siregar mengatakan bahwa hak milik bumi putera (Inlands bezitrecht) terbagi kepada dua macam yaitu:

1. Communaal bezitrecht (hak milik komunal) bila hak itu ada pada masyarakat hukum.

2. Ervelijk individueel bezitrecht (hak milik perorangan) bila hak milik itu ada pada anggota masyarakat hukum secara perorangan. ${ }^{26}$

Berdasarkan teori ini maka hak-hak individual dan persekutuan terhadap tanah dan tetap diakui keberadannya yang mana hak itu diwariskan secara turun temurun terhadap anggota keturunan masyarakat persekutuan yang mengikatkan dirinya terhadap persekutuan adat tersebut.

\section{d. Teori Hukum Nasional}

Teori hukum nasional yang dimaksudkan disini adalah hak penguasaan tanah yang didasarkan kepada UUPA Nomor 5 Tahun 1960. Dalam hal ini Hak penguasaan tanah yang berlaku secara yuridis di Indonesia tertuang dalam pasal 2 UUPA:

1) Atas dasar ketentuan dalam pasal 33 ayat 3 Undang-Undang Dasar dan hal-hal sebagai yang dimaksud dalam pasal 1, bumi, air dan ruang angkasa termasuk kekayaan alam yang terkandung didalamnya itu, pada tingkatan tertinggi dikuasai oleh negara, sebagai organisasi seluruh rakyat.

2) Hak menguasai dari Negara termaksud dalam ayat 1 pasal ini memberi wewenang untuk :

a. mengatur dan menyelenggarakan peruntukan, penggunaan, persediaan dan pemeliharaan bumi, air dan ruang angkasa tersebut;

b. menentukan dan mengatur hubungan-hubungan hukum antara orang-orang dengan bumi, air dan ruang angkasa.

3) Wewenang yang bersumber pada hak menguasai dari negara tersebut pada ayat 2 pasal ini digunakan untuk mencapai sebesar-besar kemakmuran rakyat, dalam arti kebangsaan, kesejahteraan dan kemerdekaan dalam masyarakat dan Negara Hukum Indonesia yang merdeka, berdaulat, adil dan makmur.

4) Hak menguasai dari Negara tersebut di atas pelaksanaannya dapat dikuasakan kepada Daerah-daerah Swastantra dan masyarakat-masyarakat hukum adat, sekedar diperlukan dan tidak bertentangan dengan kepentingan nasional, menuntut ketentuan-ketentuan Peraturan Pemerintah. ${ }^{27}$

Dengan berlakunya UUPA maka peraturan-peraturan pertanahan yang merupakan produk pemerintahan Hindia Belanda seperti Agrarische Wet, Agrarische Besluit, dan Buku II BW yang menagtur tentang pertanahan menjadi tidak berlaku lagi, karena memang UUPA dimaksudkan sebagai pengganti dari ketentuan-ketentuan pertanahan produk pemerintah Hindia Belanda yang terkesan imprealistik, kapitalistik dan feodalistik. Tentang kelahiran UUPA dalam semangat anti imprealistik, kapitalistik dan

\footnotetext{
${ }^{26}$ Siregar, Undang-Undang., Op.Cit., hlm. 21

${ }^{27}$ Undang-Undang Nomor 5 Tahun 1960, Pasal 2
} 
feodalistik ini Boedi Harsono sebagaimana dikutip Liliz Nur Faizah mencatat sebagai berikut:UUPA sendiri lahir dalam konteks “...perjuangan perombakan hukum agraria nasional berjalan erat dengan sejarah perjuangan bangsa Indonesia untuk melepaskan diri dari cengkraman, pengaruh, dan sisa-sisa penjajahan; khususnya perjuangan rakyat tani untuk membebaskan diri dari kekangan-kekangan sistem feodal atas tanah dan pemerasan kaum modal asing..."

Semangat menentang strategi kapitalisme dan kolonialisme yang telah menyebabkan terjadinya "penghisapan manusia atas manusia" (exploitation de l'homme par l'homme) di satu sisi; dan sekaligus menentang strategi sosialisme yang dianggap "meniadakan hak-hak individual atas tanah" di sisi lain menjadi landasan ideologis dan filosofis pembentukan UUPA. Selain itu, salah satu arti penting UUPA lainnya, bahwa hukum agraria nasional adalah berdasar hukum adat dan tidak lepas dari konteks landreform yang menjadi agenda pokok pembentukan struktur agraria saat itu. ${ }^{28}$

Menurut Subekti, ${ }^{29}$ UUPA dimaksudkan untuk mengadakan Hukum Agraria Nasiona yang berdasarkan hukum adat tentang tanah, dengan kelahiran UUPA maka tercapailah suatu keseragaman menganai hukum tanah, sehingga tidak ada lagi hak atas tanah menurut hukum Barat disamping hak atas tanah menurut hukum adat.

Hal penting tentang penguasaan tanah dalam UUPA adalah ditegaskannya hak pengusaan negara terhadap tanah, akan tetapi kendati negara diakui sebagai penguasa atas tanah bukanlah berarti negara bisa bertindak sewenang-wenang atas seluruh tanah yang ada di negara ini. Penguasaan negara ini dibatasi oleh adanya hak individu dan hak persekutuan hukum adat terhadap tanah. Dalam hal ini Kalo menjelaskan sebagai berikut:Kekuasaan negara terhadap tanah yang sudah dipunyai orang dengan sesuatu hak dibatasi oleh isi dari hak itu, artinya sampai seberapa negara memberikan kekuasaan kepada seorang yang mempunyainya untuk menggunakan haknya. Sedangkan kekuasaan negara atas tanah yang tidak dipunyai dengan sesuatu hak oleh seseorang atau pihak lain adalah sangat luas dan penuh. Misalnya negara dapat memberikan tanah yang sedemikian itu kepada seseorang atau badan hukum dengan suatu hak menurut peruntukkannya dan keperluannya, misalnya Hak Milik dan Hak Guna Usaha, Hak Guna Bangunan atau Hak Pakai ataupun dengan memberikan hak pengelolaan pada suatu badan penguasa. Dalam pada itu kekuasaan negara atas tanah-tanah ini pun sedikit atau banyak dibatasi pula oleh hak ulayat dari kesatuan-kesatuan masyarakat hukum sepanjang kenyataan hak ulayat itu masih ada. ${ }^{30}$

Berdasarkan ulasan Kalo tersebut di atas, maka penguasaan negara atas tanah dibedakan kepada dua penguasaan yaitu penguasaan langsung dan penguasaan tidak langsung. Penguasaan langsung adalah penguasaan negara terhadap tanah yang belum

28 Liliz Nur Faizah,Hak Menguasai Negara Suatu Pendekatan HistorisFilosofis, (rangkuman dari Bab II tentang Hak Menguasai Negara, dalam skripsi " Perkembangan Konsep Kepentingan Umum dalam Hukum Pengambilalihan Hak atas Tanah di Indonesia (19602006)" di Fakultas Hukum UGM Yogyakarta pada tahun 2007).http://zeilla.files.wordpress.com/2008/05/ hmn_filosofis.pdf. hlm. 4

${ }^{29}$ Subekti, Pokok-Pokok Hukum Perdata, Intermasa, (Jakarta, 1985), hlm. 93.

${ }^{30}$ Kalo, Op.Cit. hlm. 12 
dihaki perseorangan, Menurut Sunarjati Hartono ${ }^{31}$ tanah seperti ini disebut dengan istilah "tanah yang dikuasai langsung oleh negara" atau kemudian disebut secara singkat sebagai "tanah negara". Adapun hak menguasai negara secara tidak langsung adalah hak menguasai negara terhadap tanah yang telah dihaki perseorangan, atau disebut dengan "tanah yang dikuasai tidak langsung oleh negara" atau "tanah negara tidak bebas".

Menurut Imam Sutiknjo, kewenangan terhadap tanah yang sudah dihaki perseorangan ini pada dasarnya bersifat pasif, kecuali jika tanah itu dibiarkan tidak diurus/ditelantarkan. Sehingga negara dapat mengaturnya supaya produktif. ${ }^{32}$ Dengan lahirnya UUPA maka hak-hak atas tanah di Indonesia dibatasi kepada lima macam hak yaitu, hak milik, hak guna usaha, hak guna bangunan, hak pakai, dan hak sewa.

\section{Hasil Penelitian Dan Pembahasan}

\section{Penyelesaian Sengketa Melalui Lembaga Adat}

Secara sosiologis, lembaga adat diakui masyarakat dan menjadi prioritas dalam mengatur dan menyelesaikan segala persoalan di masyarakat. Penyelesaian melalui lembaga adat lebih efektif, karena suatu lembaga adat tumbuh berdasarkan nilai yang hidup dimasyarakat dan sudah diakui dan dianut secara turun temurun. Hanya saja untuk tetap menjamin kepastian hukum, maka pengaturan sebagai pengakuan masyarakat melalui perundang-undangan tetap diperlukan terutama menyangkut hal-hal yang berkaitan dengan bidang kehidupan yang netral seperti bidang administrasi, pendidikan dan lain-lain.

Mekanisme penyelesaian melalui lembaga adat selalu mengedepankan keharmonisan dan kerukunan sosial. Menjaga kerukunan sosial sangat dihargai dalam kehidupan pedesaan, dan para pelaku informal mengutamakan pemulihan hubungan sosial ketika terjadi masalah. Penyelesaian melalui lembaga adat memiliki karakter yang fleksibel. Struktur dan norma bersifat longgar untuk menyesuaikan dengan perubahan sosial. Penyelesaian sengketa melalui lembaga adat mengandalkan otoritas dan legitimasi lokal. Masyarakat lebih memilih peradilan non-negara utamanya karena otoritas para pelakunya di lingkungan pedesaan untuk memecahkan masalah dan melaksanakan putusan. Dalam sistem kelembagaan masyarakat adat Aceh terdapat syarat-syarat seperti periodisasi kepengurusan, keputusan lembaga adat tidak dapat ditawar-tawar. ${ }^{33}$

Namun penyelesaian melalui lembaga adat memiliki beberapa kelemahan utama, ${ }^{34}$ yaitu kesewenang-wenangan dan kurangnya pengawasan. Walaupun otoritas sosial menjadi kekuatan inti atas peradilan non-negara, pelaksanaannya yang tidak

\footnotetext{
${ }^{31}$ Sunarjati Hartono, Kapita Selekta Perbandingan Hukum, (Bandung: Alumni, 1986), hlm. 63.

${ }^{32}$ Imam Sutiknjo, Politik Agraria Nasional, Gadjah Mada University Press, (Yogyakarta, 1994), hlm. 53.

${ }^{33}$ Wawan cara dengan Abdulah Tokoh Masyarakat Adat Aceh , di Kantor Lembaga Adat Aceh Langsa, 12 Mei 2019 (diolah).

${ }^{34}$ Justice for the Poor, Titik Keseimbangan: Mempertimbangkan Keadilan Non-negara di Indonesia, World Bank, Mei 2009, hal. 41
} 
dikontrol menjadi kelemahan utama. Kurangnya prosedur dan norma yang jelas dan tidak adanya akuntabilitas akan membuat pihak yang lemah dan terpinggirkan kurang dilayani, tanpa alternatif lain.

Prinsip dasar penyelesaian sengketa melalui lembaga adat:

1. Memperhatikan norma-norma adat ideal dan produler dan budaya.

2. Biaya murah/bahkan tidak ada biaya, sederhana dan cepat selesai.

3. Keadilan sosial diutamakan yang bermuara kepada kemanfaatan Hukum. ${ }^{35}$

Musyawarah merupakan model umum dan yang utama dalam proses sidang dalam peradilan adat. Ini berarti institusi peradilan adat, tidak hadir dengan misi utama untuk menjadi sarana pemaksa. Peran mediator untuk rekonsiliasi dan konsolidasi para pihak, melalui proses penemuan putusan yang melegakan semua pihak, termasuk masyarakat umum dari komunitasnya yang tidak terkait langsung dengan kasus tersebut merupakan ciri penting dari mekanisme penyelesaian sengketa melalui lembaga adat.

Model penyelesaian sengketa dengan metode musyawarah tersebut, membuat peradilan adat lolos dari perangkap putusan yang tidak bisa dijalankan. Karena prinsipnya, putusan diambil secara sukarela oleh para pihak. Tidak ada kecurigaan dan prasangka terhadap keputusan yang diambil. Karena semua prosenya dilakukan secara terbuka yang memungkinkan semua pihak menyampaikan seluruh informasi secara bebas, tanpa harus memikirkan aspek formal.

Namun, dari beberapa praktek itu juga dapat dilihat bahwa masyarakat adat paling tidak tergambar dari putusan peradilan adat juga tidak membuat keputusan yang final. Bahkan ada juga yang menyerahkan kepada peradilan formal jika ada pihak yang tidak puas dengan putusannya. Ada kecurigaan bahwa praktek semacam ini disebabkan karena melemahnya kepercayaan diri para fungsionaris adat sehingga berharap pada sistem hukum yang lain.

Pembatasan waktu penyelesaian sengketa sangat tergantung pada kedua belah pihak yang bersengketa apabila telah mencapai rasa keadilan sosial dengan menjaga keseimbangan sosial jangan sampai terganggu. Setiap sengketa dapat diselesaikan melalui dua mekanisme, yaitu mekanisme litigasi atau dengan alternatif peyelesaian sengketa. Penyelesaian sengketa melalui lembaga adat adalah salah satu alternatif penyelesaian sengketa diluar jalur ligitigasi (peradilan). Maka jika alternatif ini tidak berhasil, maka dapat dilakukan dengan alternatif lain, misalnya konsultasi, jasa baik, arbitrase, dan jika semua alternatif tersebut juga tidak berhasil, maka dapat dilakukan dengan jalur pengadilan sebagai alternatif terakhir.

DiAceh mekanisme penyelesaian sengketa melalui Lembaga Adat didukung oleh sejumlah peraturan perundang-undangan. Di dalam berbagai peraturan perundangundangan tersebut dinyatakan secara tegas bahwa penguatan hukum adat dan peradilan adat harus dimulai dari Gampong dan Mukim. Adapun badan-badan resmi yang menyelenggarakan peradilan adat yaitu Lembaga Gampong dan Lembaga Mukim. Secara hirarki kronologis dasar hukum peradilan adat adalah:

\footnotetext{
${ }^{35}$ Hasil diskusi Dosen Hukum di Fakultas Hukum Universitas Sains Cut Nyak Dhien Langsa, 1 Mei 2019 (diolah)
} 
Pertama Pasal 18 B ayat (2) Undang - Undang Dasar 1945 berbunyi "Negara mengakui dan menghormati kesatuan-kesatuan masyarakat hukum adat beserta hak-hak tradisionalnya sepanjang masih hidup dan sesuai dengan perkembangan masyarakat dan prinsip-prinsip Negara Kestauan Indonesia yang diatur dalam undang-undang”.

Kedua Undang-Undang Nomor 44 Tahun 1999 tentang Penyelenggaraan Keistimewaan Provinsi Daerah Istimewa Aceh Pasal 3 ayat (1) menyebutkan keistimewaan merupakan pengakuan dari Bangsa Indonesia yang diberikan kepada daerah karena perjuangan dna nilai-nilai hakiki masyarakat yang tetap dipelihara secara turun temurun sebagai landasan spiritual, moral, dna kemnausiaan. Pada ayat (2) disebutkan bahwa penyelenggaraan Keistimewaan meliputi:

1. Penyelenggaraan kehidupan beragama

2. Penyelenggaraan kehidupan adat

3. Penyelenggaraan pendidikan

4. Peran ulama dalam penetapan kebijakan daerah

Dalam hal penyelenggaraan kehidupan adat, dalam Pasal 6 ditegaskan daerah dapat menetapakan berbagai kebijakan dalam upaya pemberdayaan, pelestarian dna pengembangan adat serta lembaga adat di wilayahnya yang dijiwai dan sesuai dengan Syariat Islam.

Ketiga Undang-Undang Nomor 11 Tahun 2006 tentang Pemerintahan Aceh, Pasal 98 ayat (2) mengatakan bahwa penyelesaian masalah sosial kemasyarakatan secara adat ditempuh melalui Lembaga Adat

Keempat Qanun Propinsi Nanggroe Aceh Darusslaam Nomor 4 Tahun 2003 tentang Pemerintahan Mukim memberikan wewenang kepada Mukim untuk:

1. Memutuskan dan atau menetapkan hukum

2. Memelihara dan mengembangkan adat

3. Menyelenggarakan perdamaian adat

4. Menyelesaiakn dna memberikan keputusan-keputusan adat terhadap perselisihanperselisihan dna pelanggaran adat

5. Memberikan kekuatan hukum terhadap sesuatu hal dan pembuktian lainnya menurut adat

6. Menyelesaikan perkara-perkara yang berhubungan dengan adat dan adat istiadat.

Qanun Provinsi Nanggroe Aceh Darussalam Nomor 5 Tahun 2003 tentang Pemerintahan Gampong, menegaskan bahwa tugas dan kewajiban pemerintahan Gampong adalah:

1. Menyelesiakan sengketa adat

2. Menjaga dan memelihara kelestarian adat dan istiadat

3. Memelihara ketentraman dna ketertiban serta mencegah munculnya perbuatan maksiat dalam masyarakat

4. Bersama dnegan Tuha Peut dan Imum Meunasah menjadi hakim perdamaian.

Kelima Qanun Aceh Nomor 9 Tahun 2008 tentang Pembinaan Kehidupan Adat dan Adat Istiadat pada Ketentuan Umum Pasal 1 angka 10 menyeutkan bahwa adat 
adalah aturan perbuatan dan kebiasaan yang telah berlaku dalam masyarakat yang dijadikan perodman dalam pergaulan hidup di Aceh. Dalam angka 11 nya menyebutkan Hukum Adat adalah seperangkat ketentuan tidka tertulis yang hidup dna berkembang dalam masyarakat Aceh, yang memiliki sanksi apabila dilanggar.

Qanun Aceh Nomor 10 Tanun 2008 tentang Lembaga Adat pada Ketentuan Umum Pasal 1 angka 9 menyebutkan Lembaga Adat adalah suatu organisasi kemasyarakatan adat yang dibentuk oleh suatu masyarakat hukum adat tertentu mempunyai wilayah tertentu dan mempunyai harta kekayaan tersendiri serta berhak dan berwenang untuk mengatur dan mengurus serta menyelesaikan hal-hal yang berkaitan dengan adat Aceh.

Keenam Peraturan Gubernur Aceh Nomor 25 Tahun 2011 tentang Pedoman Umum Penyellenggaraan Pemerintahan Gampong Pasal 1 Angka 18 disebutkan bahwa Lembaga Adat adalah suatu organisasi kemasyarakatan adat yang dibentuk oleh suatu masyarakat hukum adat tertentu dan mempunyai harta kekayaan tersendiri serta berhak dan berwenang untuk mengatur dan mengurus serta menyelesaikan hal-hal yang berkaitan dengan adat Aceh.

Dalam Pasal 5 juga disebutkan pedoman umum penyelenggaraan pemeirntahan Gampong, salah satunya adalah penyelesaian sengketa menurut penyelenggaraan pemerintahan Gampong, salah satunya adalah penyelesaian sengketa menurut hukum adat. Dalam Lampiran Peraturan Gubernur tersebut juga menjelaskan bahwa salah satu tugas Tuha Peut Gampong adalah menyelesaikan sengketa yang timbul dalam masyarakat bersama geuchik dan pemangku adat.

Surat Keputusan Bersama Gubernur Aceh, Kapolda Aceh dan Ketua Majelis Adat Aceh No: 198/677/2011/No:1054/MAA/XII/2011/No:B/121/I/2012 tentang Penyelenggaraan Peradilan Adat Gampong dan Mukim atau nama lain di Aceh, mengeluarkan keputusna diantaranya:

1. Sengketa/perselisihan yang terjadi ditingkat gampong dna mukim yang bersifat ringan sebagaimana diatur dalam Pasal 13, 14, 15 Qanun No. 9 Tahun 2008 wajib diselesaikan terlebih dahulu melalui Peradilan Adat Gampong dan Mukim.

2. Aparat kepolisian memberikan kesempatan agar setiap sengketa/perselisihan sebagaimana dimaksud pada point ke satu untuk diselesaikan terlebih dahulu melalui Peradilan Adat gampong atau mukim.

3. Semua pihak wajib menghormati penyelenggaraan Peradilan adat Gampong dan Mukim.

4. Peradilan Adat Gampong atau Mukim dalam penyelesaiannyadapat member putusan berdasarkan pada norma hukum adat dan adat istiadat yang berlaku di daerah setempat.

5. Persidangan Peradilan Adat Gampong dan Mukim dihadiri oleh para pihak, saksisaksi dan terbuka untuk umum, kecuali untuk kasus-kasus tertentu yang menurut adat dan kepatutan tidka boleh terbuka untuk umum.

6. Putusan Peradilan Adat Gampong dan Mukim bersifat final dna mengikat serta tidak dapat diajukan lagi pada peradilan umum atau peradilan lainnya. 
7. Setiap peradilan adat gamping dna mukim dibuat secara tertulis, ditandatangani oleh ketua dan anggota majelis serta kedua belah pihak yang bersengketa dan tembusannya disampaikan kepada Kapolsek, Camat serta MAA Kecamatan.

8. Penyelenggaraan Peradilan Adat Gampong dan Mukim dalam memberikan keputusan, tapi dilaran menjatuhkan sanksi badan, seperti pidana penjara, memandikan dengan air kotor, mencukur rambut, menggunting pakaian dna bentuk-bentuk yang bertentangan dengan nilai-nilai islami.

9. Perkara yang diselesaikan ditingkat mukim adalah perkara yang tidak selesai ditingkat gampong.

10. Pemerintah Aceh dan Pemerintah Kabupaten/Kota membina dan mengawasi pelaksanaan peradilan adat gampong dan mukim di Aceh.

11. Kapolda dan Ketua MAA beserta seluruh jajarannya berkewajiban member bimbingan, pembinaan, pengembangan dan pengawasan materi Hukum Adat dan Administrasi Peraidlan adat sesuai dengan tatanan dan asas-asas Hukum Adat yang berlaku pada masyarakat setempat.

12. Pemerintah Aceh dan Pemeirntah Kabupaten/Kota dapat membantu pembiayaan administrasi untuk penyelenggaraan Peradilan Adat Gampong dan Mukim.

13. Majelis Peradilan Adat Gampong dan Mukim dan tata cara penyelesaian sengketa/perselisihan berpedoman pada Qanun Aceh No 9 Tahun 2008 dan Pertauran Gubernur Aceh Nomor 25 Tahun 2011 tentang Pedoman Umum Penyelenggaraan Pemerintahan Gampong.

Dengan adanya peraturan-pertauran tersebut telah memperkuat untuk melaksanakan peradilan adat di Aceh, yang pada kenyataannya orang-orang Aceh (Geuchik di Gampong) masih menerapkan dan mempertahankan hukum adat menyangkut penyelesaian hukum adat atau delik.

Beberapa asas dasar dalam pelaksanaan peradilan adat di Aceh diantarannya adalah:

1. Terpercaya atau amanah, maksudnya peradilan adat didasari pada kepercayaan masyarakat terhadap para tokoh-tokoh adatnya.

2. Tanggungjawab, maksudnya pelaksanaan peradilan adat didasari tanggungjawab dalam pelaksanaannya kepada para pihak, masyarakat dan Allah swt.

3. Kesetaraan di depan hukum, maksunya peradilan adat tidak boleh membedabedakan jenis kelamin, status sosial, umur ddan lain-lain. Semua orang mempunyai kedudukan dan hak yang sama di depan hukum adat.

4. Cepat, murah dan mudah, maksudnya proses peradilan adat dilaksanakan secara cepat, tidak boleh mengulur-ngulur waktu, dan mudah. Putusannya harus terjangkau untuk dilaksanakan oleh masyarakat.

5. Ikhlas dan sukarela, artinya para tokoh adat tidak boleh memaksa para pihak untuk menyelesaiakn perkaranya melalui peradilan adat.

6. Penyelesaian damai, maksudnya peradilan adat ini dimaksudkan untuk benarbenar menyelesaiakn masalah yanag ada, guna mengembalikan keseimbangan dann kerukunan hidup masyarakat. 
7. Musyawarah atau mufakat, maksudnya keputusan yang diambil dalam peradilan adat didasari pada hasil musyawarah mufakat yang berlandaskan hukum adat dan agama Islam.

8. Keterbukaan dan umum, maksudnya semua proses peradilan adat dilaksanakan secara terbuka (kecuali untuk kasus tertentu, seperti perkara keluarga).

9. Jujur, artinya pelaksanaan peradilan adat dilakukan secara jujur. Setiap pemimpin adat tidak boleh mengambil keuntungan dalam bentuk apapun baik materil maupun non materil dalam penanganan perkara.

10. Keberagaman artinya peradilan adat menghargai keberagaman ketentuan adat dalam berbagai sub system hukum adat yang berlaku dalam masyarakat.

11.Praduga tidka bersalah, maksdunya hukum adat tidak membenarkan adanya tindakan main hakim sendiri. Dalam proses peradilan para pihak harus dianggap tidak bersalah sampai adanya putusan.

12.Berkeadilan, maksudnya putusan peradilan adat harus bersifat adil dan putusannya diterapkan dengan kualitas perkara dan tingkat ekonomi para pihak. ${ }^{36}$

Hukum adat mengatur segala hal yang berhubungan dengan pergaulan dalam masyarakat, meliputi hukum adat tentang tanah, hukum adat tentang transaksi tanah, hukum adat tentang perutangan, hukum adat tentang status badan pribadi, hukum adat tentang kekerabatan, hukum adat tentang perkawinan, hukum adat tentang waris dan hukum adat tentang delik data.

Penyelesaian melalui lembaga adat dapat mencakup beberapa bidang hukum,yaitu hukum privat (perdata), pidana dan tata negara. Untuk penyelesaian melalui mekanisme arbitrase dan mediasi maka putusan lembaga adat bersifat final. Kemudian untuk kasus hukum privat (perdata) menjadi peradilan pertama sedangkan untuk hukum publik (pidana dan tata negara) menjadi peradilan pertama. ${ }^{37}$

Perlu dicatat bahwa peradilan gampong dapat dilakukan oleh lembaga adat tersebut. Peradilan dilakukan dengan menempuh jalan musyawarah dan mufakat tanpa melalui prosesperadilan dengan melibatkan lembaga peradilan sebagaimana biasanya. Penyelesain sengketa, konflik dan berbagai macam kasus dalam gampong dapat diselesaikan dengan jalan damai, yang dibiasa disebut penyelesaian sengketa di luar peradilan atau ADR (alternative dispute resolution). ADR merupakan salah satu langkah untuk meningkatkan akses terhadap penegakan dan perwujudan keadilan atau accesess to justice. Karena dapat digunakan untuk menyelesaikan suatu permasalahan di luar peradilan umum kepada suatu forum yang lebih murah, cepat, dekat dan tidak mengintimidasi. ${ }^{38}$

\footnotetext{
${ }^{36}$ Majelis Adat Aceh Prinsip-prinsip Dasar Pelaksanaan Peradilan Adat (1), Aceh, 2008, hlm. 3 .

${ }^{37}$ Andiko, Sistem Penyelesaian Sengketa Alternatif Melalui Lembaga Adat : Kemana Harus Melangkah (HuMA) Focus Group Discusion (FGD) Dalam Rangka Penelitian Sistem Alternatif Penyelesaian Sengketa Melalui Lembaga Adat, 7 Desember 2012 Ruang Rapat KPUS P3DI Setjen

${ }^{38}$ Emmy Yuhassarie dan Tri Harnomo (ed), Mediasi dan Court Annexed Mediation: Prosiding Rangkaian Lokakarya Terbatas Masalah-Masalah Kepailitan dan Wawasan Hukum
} 
Lembaga adat yang ada di Aceh melakukan tugas dan fungsinya sebagai lembaga penyelesaian sengketa diluar pengadilan. Antara fungsi lembaga adat dan penerapan ADR nampaknya mempunyai kecocokan karena sistem sosial, adat dan budaya Aceh berdasarkan musyawarah dan mufakat, ADR juga mempunyai semangat yang sama. Beberapa hal di bawah ini merupakan keuntungan jika penyelesaian sengketa dan konflik dilakukan melalui jalur ADR, yaitu;

1. Sifat kesukarelaan dalam proses;

2. Prosedur yang tepat;

3. Keputusan non-yudisial;

4. Kontrol tentang kebutuhan organisasi;

5. Prosedur rahasia (confidential);

6. Fleksibilitas dalam merancang syarat-syarat penyelesaian masalah;

7. Hemat waktu;

8. Hemat biaya;

9. Pemeliharaan hubungan (silaturrahmi terjaga);

10.Tinggi kemungkinan untuk melaksanakan kesepakatan;

11. Kontrol dan lebih mudah memperkirakan hasil; dan

12.Keputusan bertahan sepanjang waktu. ${ }^{39}$

Dalam prakteknya peradilan adat hanya dapat memeriksa sengketa yang timbul antara anggota masyarakat adat dalam satu komunitas. Dalam praktik, peradilan adat sangatlah sulit diterapkan pada sengketa tanah yang mempertemukan masyarakat adat dengan pihak lain semisal pemerintah dan perusahaan. Karena itu maka jalan keluar yang ditempuh komunitas selama ini biasanya melalui cara-cara negosiasi. Cara ini dipilih karena masyarakat adat menyadari bahwa kelemahan status hukum (formal) masyarakat adat atas wilayah adatnya akan menyulitkan mereka mencapai keadilan jika penyelesaiannya dilakukan melalui peradilan negara. Sementara di sisi lain, tidaklah mungkin memaksa pemerintah dan perusahaan untuk tunduk pada hukum adat yang karenanya penyelesaian sengketa dapat dilakukan melalui peradilan adat. Cara ini biasanya dipakai oleh masyarakat adat untuk memperjuangkan status hukum (formal) kepemilikan mereka atas wilayah adat.

Sikap pengadilan negeri terhadap putusan lembaga adat menunjukan pentingnya menggali nilai-nilai adat yang sudah diamanatkan oleh UU. Putusan lembaga adat belum menjadi bahan pertimbangan dalam putusan pengadilan negeri apabilah salah satu pihak melanjutkan perkaranya ke pengadilan negeri. Apabila masalah tidak diselesaikan dilembaga adat biasanya dilakukan secara lintas budaya untuk keabsahan masalah yang diselesaikan, atau di bawah ke kepolisian tetapi materi penyelesaian menggunakan hukum adat. Bahkan jika salah satu pihak tidak puas bisa dilanjutkan ke Pengadilan Negeri.

Bisnis Lainnya Tahun 2004, Jakarta 17-18 Februari 2004 (Jakarta: Pusat Pengkajian Hukum, 2004), hlm. . 141.

${ }^{39}$ Ibid 
Faktor utama yang turut mempengaruhi penyelesaian sengketa melalui budaya adat adalah budaya malu karena masyarakat adat mengutamakan kehidupan secara solidaritas sosial dengan menjaga keseimbangan kehidupan sosial di masyarakat adat (Kosmis). Upaya yang diperlukan untuk memperkuat kedudukan dan peran lembaga adat dalam penyelesaian sengketa adalah memperjelas kedudukan dan peran lembaga adat dalam pembentukan lembaga adat sebagai lembaga kemasyarakat gampong dan juga sebagai mitra pemerintah gampung dan pemerintah daerah dalam bentuk kebijakan (regulasi) di setiap daerah di Aceh.

Putusan lembaga adat biasanya dilaksanakan secara sukarela oleh masing-masing pihak dan tidak menuntut proses eksekusi sebagaimana dalam putusan pengadilan. Tidak dilakukan keberatan terhadap putusan lembaga adat, sebab biasanya keputusan dibuat berdasarkan kesepakatan para pihak, jika masih ada pihak yang belum bersepakat maka keputusan belum akan diambil.

Sanksi yang ditetapkan oleh lembaga adat lebih banyak berupa sanksi sosial, misalnya sengketa yang terjadi menjadi "buah bibir" masyarakat, sehingga para pihak merasa malu dan ini merupakan salah satu efek jerah yang dapat ditimbulkan oleh sanksi sosial tersebut. Pada umumnya implementasi atau eksekusi dari pemutusan lembaga adat di umumkan secara terbuka kepada warganya secara lisan melalui toko-toko yang terlibat menyelesaikan perkara/ sengketa dan tokoh adat lain yang memiliki hubungan Klen atau warganya masing-masing.

\section{Lembaga Adat Sebagai Alternatif Dalam Penyelesaian Perkara Sengketa Pertanahan di Aceh}

Pelaksanaan peradilan adat yang menyerupai persidangan formil, pelaksanaannya dinilai lebih sistematis dan merujuk pada Pedoman Peradilan Adat yang diterbitkan oleh Majelis Adat Aceh. ${ }^{40}$ Selain para pihak yang bersengketa, dalam pelaksanaan peradilannya memiliki struktur tertentu yaitu adanya Geuchik sebagai ketua majelis peradilan, dan Tuha Peut Gampong, Imuem Meunasah dan Ulama, Cendikiawan, serta Tokoh Adat lainnya sebagai anggota. Formasi ini dilengkapi oleh Panitera yang dijabat oleh Sekretaris Gampong yang memiliki peranan sebagaimana panitera pada persidangan yaitu mencatat jalannya agenda sidang dalam berita acara persidangan. Dalam penyelesaian perkara yang dipandang berat dan melibatkan lebih banyak orang, misalnya perselisihan antar warga ataupun perselisihan sengketa tanah maka proses peradilan akan mengambil tempat di kantor Geuchik atau di Meunasah. Biasanya agenda persidangan akan dibuka secara resmi oleh Geuchik, dan kerap kali dihadiri oleh masyarakat sekitar, penyelesaian seperti inilah yang dilakukan oleh aparatur gampong. Sidang dilakukan lebih kurang empat kali atau lebih.

Kemudian, kedua belah pihak diundang secara resmi oleh Hakim Peradilan Adat Gampong untuk didengarkan keterangannya di hadapan sidang peradilan adat yang mengambil tempat di Meunasah Gampong. Pada tahap ini, masing-masing pihak

${ }^{40}$ MAA, Pedoman Peradilan Adat Aceh - Untuk Peradilan Adat Yang Adil dan Kompatibel,( Nanggroe Aceh Darussalam, 2008 ), hlm. 5-6 
diberikan kesempatan oleh Hakim Peradilan Adat untuk menyampaikan keluhan dan laporannya, dan setelah mendengarkan kedua belah pihak, hakim peradilan adat beserta aparatur meminta kesediaan dari para pihak untuk mediasi.

Tahap berikutnya, merupakan tahap pembuktian dan pendalaman atas sengketa yang berlangsung. Pada tahap ini sebagaimana tahap-tahap sebelumnya, Majelis Hakim pada peradilan adat di gampong tetap menghimbau kepada masing-masing pihak untuk ishlah atau berdamai saja dan tidak melarut-larutkan permasalahan ini, terutama dengan mempertimbangkan bahwa sengketa terjadi antara dua pihak. Pada proses persidangan secara adat ini, selain memperhatikan bukti-bukti yang muncul selama proses berlangsung, pihak aparatur gampong juga menelusuri track record masing-masing pihak terutama dari aspek hubungan kemasyarakatan kedua pihak. Menurut pihak aparatur gampong, mengkaji hubungan kemasyarakatan yang dimiliki masing-masing pihak adalah penting untuk menentukan penyelesaian sengketa diantara keduanya. Para pihak dikuatkan untuk penyelesaian damai, namun jika ternyata salah satu pihak atau keduanya keberatan maka sengketa akan diselesaikan di pengadilan negeri.

Keberadaan para pemimpin adat sebagaimana disampaikan di atas memiliki beberapa tanggung jawab, yaitu pertama, menyelenggarakan proses peradilan adat dalam setiap tahapannya, dimulai dari menerima laporan, memeriksa duduk persoalan sampai dengan tahap pengambilan putusan. Kedua, menjatuhkan putusan dengan adil dengan didasarkan pada bukti-bukti yang dapat dipertanggungjawabkan serta memenuhi rasa keadilan para pihak. Ketiga, melindungi hak-hak para pihak bersengketa dalam setiap tahapan prosesnya, termasuk mendengarkan secara berimbang. Keempat, mencatat proses dan keputusan peradilan adat secara akurat dan memenuhi prinsip pendokumentasian dan administrasi. Terakhir, kelima - tanggung jawab pemangku adat adalah untuk mengarsipkan berkas perkara dengan baik dan aman. Fungsi pengarsipan iniadalah sebagai data dukung dalam hal terjadinya pengulangan sengketa atau perselisihan, maka pemangku adat memiliki bukti dan referensi dalam melakuka peradilan serta mengambil keputusan.

Ketika perselisihan dan sengketa antara kedua belah pihak telah mendapatkan titik temu, maka menurut praktek adat yang berlaku di Aceh, para pihak akan didamaikan. Proses ini dikenal dengan istilah peudame (melakukan perdamaian atau berdamai), suloh (jalan damai atau perdamaian antara dua individu yang berselisih tetapi tidak sampai berdarah), diet (sejenis perdamaian dengan unsur ganti disertai dengan peusijuek), serta sayam dan peusijuek (sejenis perdamaian antar pihak/kelompok masyarakat/antar Gampong yang bertikai dalam hal mana para pihak bersengketa menjadi korban dan mengeluarkan darah. Setelah peusijuek selesai maka dilanjutkan dengan prosesi peumat jaroe (saling berjabat tangan) antara pihak yang bersengketa. Kegiatan ini dilakukan (difasilitasi) oleh keuchik, teugku imuem dan tertua adat. Peumat jaroe merupakan simbol perbaikan hubungan antara para pihak yang bersengketa, dengan harapan konflik antar mereka dapat segera berakhir. Oleh karena itu, dalam proses peumat jaroe, pihak yang memfasilitasi mengucapkan kata-kata khusus seperti: "Nyoe kasep oh no bek na dendam le, nyoe beujeut keu jalinan silaturahmi, karena nyan ajaran agama geutanyoe". (artinya, 
masalah ini sudah cukup sampai disini dan jangan diperpanjang lagi, bersalaman ini diharapkan menjadi awal jalinan silaturahmi, sebab ini ajaran agama kita). ${ }^{41}$

Qanun Aceh Nomor 10 Tanun 2008 tentang Lembaga Adat yang dilakukan oleh lembaga Gampong, dan dalam hal sengketa tidak mendapatkan penyelesaiandi tingkat Gampong, maka Mukim memiliki kewenangan untuk menyelesaikannya. Dalam pelaksanaan peradilan adat di tingkat Gampong maupun mukim, diakui masih belum optimal dikarenakan beberapa hal seperti kurangnya pemahaman geuchik dan aparatur Gampong lainnya terhadap mekanisme maupun substansi permasalahan yang disengketakan maupun mekanisme peradilan yang harus ditempuh. Figur Geuchik dan gaya komunikasi Geuchik yang dinilai tidak arif, serta kurangnya rasa percaya masyarakat atas keputusan yang ditetapkan oleh majelis perdamaian di Gampong juga memberi andil terhadap lemahnya pelaksanaan peradilan adat,38 namun demikian, kondisi ini tidak menyebabkan berhentinya praktek-praktek penyelesaian sengketa dimaksud.

\section{Penutup}

\section{Simpulan}

Penelitian ini sampai pada beberapa kesimpulan, yaitu: Pertama, secara yuridis pengaturan mengenai lembaga adat termasuk perannya sebagai lembaga alternatif penyelesaian sengketa masih belum sempurna, mengambang, dan sektoral. Hal ini menunjukkan bahwa secara kelembagaan mekanisme penyelesaian sengketa melalui lembaga adat masih menghadapi banyak kendala. Politik hukum nasional yang mengedepankan unifikasi hukum masih dirasakan dampaknya secara yuridis sampai saat ini. Kedua, terkait dengan kewenangan lembaga menyelesaikan sengketa bahwa lembaga adat memiliki struktur, tugas dan fungsi serta kompetensinya. Mekanisme utama yang digunakan dalam penyelesaian sengketa adalah mekanisme musyawarah. Putusan lembaga adat memiliki wibawa yang kuat sehingga banyak yang diikuti, namun dalam hal tertentu pihak yang berkeberatan dapat menyelesaikan sengketa melalui lembaga penyelesaian sengketa Negara. Kompetensi dari lembaga adat meliputi aspek hukum privat dan hukum publik. Ketiga, upaya yang dilakukan oleh beberapa daerah untuk memperkuat posisi dan peran lembaga adat adalah melalui pembentukan Qanun Aceh Nosmor 10 Tanun 2008 tentang Lembaga Adat.

${ }^{41}$ Mahmudin., et.al, "Nilai Lokal dan Konflik Aceh: Studi Dimensi Budaya Dalam Penguatan Civil Society", Laporan Penelitian, (Banda Aceh: Satker BRR Revitalisasi dan Pengembangan Kebudayaan NAD, 2006); Lihat juga Syahrizal, Mediasi Dalam Hukum Syariah, Hukum Adat dan Hukum Nasional, (Jakarta: Kencana, 2011) 


\section{Saran}

Beberapa saran yang dapat disampaikan adalah pertama, ketentuan dalam UndangUndang Pasal 18B ayat (2) UUD 1945 perlu ditindaklanjuti dengan UndangUndang tentang Pengakuan dan Perlindungan HakHak Masyarakat Adat. Melalui UndangUndang tersebutlah peran lembaga adat dalam menyelesaikan sengketa semakin jelas dan kuat. Saran kedua adalah upaya penguatan Lembaga adat yang dilakukan oleh Pemerintah Aceh contoh bagi daerah lain dalam membangun dan memperkat keberadaan lembaga adat.

\section{DAFTAR PUSTAKA}

Andiko, Sistem Penyelesaian Sengketa Alternatif Melalui Lembaga Adat : Kemana Harus Melangkah (HuMA) Focus Group Discusion (FGD) Dalam Rangka Penelitian Sistem Alternatif Penyelesaian Sengketa Melalui Lembaga Adat, 7 Desember 2012 Ruang Rapat KPUS P3DI Setjen

Boedi Harsono, Hukum Agraria Indonesia: Sejarah Pembentukan Undang-Undang Pokok Agraria, Isi dan Pelaksanaannya, Djambatan, Jakarta, 1999

Dewa Gede Atmadja dan I Nyoman Putu Budiartha, Teori-teori Hukum, Setera Press, Malang, 2018

Emmy Yuhassarie dan Tri Harnomo (ed), Mediasi dan Court Annexed Mediation: Prosiding Rangkaian Lokakarya Terbatas Masalah-Masalah Kepailitan dan Wawasan Hukum Bisnis Lainnya Tahun 2004, Jakarta 17-18 Februari 2004 (Jakarta: Pusat Pengkajian Hukum, 2004)

H. Ali Achmad Chomzah, Hukum Agraria (pertanahan Indonesia) Jilid 1, Jakarta, Prestasi pustaka, 2004

Harta sehareukat adalah harta bersama yang memiliki hubungan kekeluargaan antara suami dan istri baik itu salah satu bercerai akibat meninggal dunia maupun bercerai ketika masih hidup, dalam Syahrizal, Hukum Adat dan hukum Islam di Indonesia, Nadiya Foundation Nanggroe Aceh, Banda Ace, 2004

Heru Kuswanto, Hukum Agraria, (Modul) Fakultas Hukum Universitas Narotama, Surabaya, 2011

Imam Sutiknjo, Politik Agraria Nasional, Gadjah Mada University Press, Yogyakarta, 1994

Justice for the Poor, Titik Keseimbangan: Mempertimbangkan Keadilan Non-negara di Indonesia, World Bank, Mei 2009 
Liliz Nur Faizah, Hak Menguasai Negara Suatu Pendekatan HistorisFilosofis, (rangkuman dari Bab II tentang Hak Menguasai Negara, dalam skripsi " Perkembangan Konsep K epentingan U mum dalam Hukum Pengambilalihan Hak atas Tanah di Indonesia (1960-2006)" di Fakultas Hukum UGM Yogyakarta pada tahun 2007).http://zeilla.files.wordpress.com/2008/05/ hmn_filosofis.pdf. halaman 4

MAA, Pedoman Peradilan Adat Aceh - Untuk Peradilan Adat Yang Adil dan Kompatibel, Nanggroe Aceh Darussalam, 2008

Mahmudin., et.al, "Nilai Lokal dan Konflik Aceh: Studi Dimensi Budaya Dalam Penguatan Civil Society", Laporan Penelitian, Satker BRR Revitalisasi dan Pengembangan Kebudayaan NAD, Banda Aceh, 2006; Lihat juga Syahrizal, Mediasi Dalam Hukum Syariah, Hukum Adat dan Hukum Nasional, Kencana, Jakarta, 2011

Majelis Adat Aceh Prinsip-prinsip Dasar Pelaksanaan Peradilan Adat (1), Aceh, 2008

Subekti, Pokok-Pokok Hukum Perdata, Intermasa, Jakarta, 1985

Sunarjati Hartono, Kapita Selekta Perbandingan Hukum, Alumni, Bandung, 1986

Syafruddin Kalo, Perbedaan Persepsi Mengenai Penguasaan Tanah dan Akibatnya Terhadap Masyarakat Petani di Sumatera Timur pada Masa Kolonial yang Berlanjut pada Masa Kemerdekaan, Orde Baru dan Reformasi, Program Studi Hukum Pidana Fakultas Hukum Universitas Sumatera Utara, t.t.

Tampil Anshari Siregar, Undang Undang Pokok Agraria dalam Bagan,Kelompok Studi Hukum dan Masyarakat Fakultas Hukum USU, Medan, 2011

Umar Kusumo Haryono, Eksistensi Tanah Kasultanan (Sultan Ground) Yogyakarta Setelah Berlakunya UU No. 5 / 1960, Yustisia Edisi Nomor 68 Mei - Agustus 2006

Yusi Amdani, Proses Penyelesaian Perselisihan di lembaga peradilan adat Aceh Tingkat Gampong (Desa), Jurnal Ilmu Asyari' ah dan hukum Vol. 48 No. 1, Juni 2014

Zuryawan Isvandiar Zoebir, Bayang-Bayang Cultuurstelsel Dan Domein Verklaring Dalam

Politik Agraria,http://zuryawanisvandiarzoebir.wordpress.com/2008/11/07/ bayang-bayang-cultuurstelsel-dan-domein-verklaring-dalam-praktik-politikagraria/, (7 Juni 2019). 